Tarih Kültür ve Sanat Araştırmaları Dergisi

Revue des Recherches en Histoire Culture et Art

مجلة البحوث التاريخية و الثقافية والفنية
Vol. 6, No. 2, March 2017

Copyright (C) Karabuk University

http://kutaksam.karabuk.edu.tr

\title{
DOI: 10.7596/taksad.v6i2.
}

Citation: Kılcan, B., Akbaba, B., \& Gülbudak, B. (2017). Altıncı ve Yedinci Sınıf Öğrencilerinin Hoca Ahmed Yesevî Algıları. Journal of History Culture and Art Research, 6(2), 549-564. doi:http://dx.doi.org/10.7596/taksad.v6i2.809

\section{Altıncı ve Yedinci Sınıf Öğrencilerinin Hoca Ahmed Yesevî Algıları*}

\author{
Sixth and Seventh Graders' Perceptions of Khoja Ahmad Yassawi \\ Bahadır Kılcan ${ }^{1}$, Bülent Akbaba ${ }^{2}$ \\ Burcu Gülbudak ${ }^{3}$
}

\begin{abstract}
The purpose of this research is to determine sixth and seventh graders' perceptions of Khoja Ahmad Yassawi, who was among Turkish-Muslim thinkers, covered in the sixth and seventh grades social sciences curriculum. To this end, the metaphors produced and the pictures/cartoons drawn by the students about Khoja Ahmad Yassawi were examined. Qualitative research designs were employed in the research. The study group consists of 237 sixth and seventh graders educating in Mamak district of Ankara province in the spring semester of the 2015-2016 academic year. The data obtained from the participants were analyzed and interpreted via content analysis. The participants were found to have the following perceptions of Khoja Ahmad Yassawi: "informing, advisory", "guiding, illuminating", "showing the truth, providing benefit", and "leaving a mark, esteemed".
\end{abstract}

Keywords: Khoja Ahmad Yassawi, Social sciences, Middle school, Metaphor, Qualitative research.

$\ddot{O} z$

$\mathrm{Bu}$ araştırmada, sosyal bilgiler 6 ve 7 . sınıf öğretim programında yer alan Türk-İslam mütefekkirlerinden Hoca Ahmed Yesevi'nin altıncı ve yedinci sınıf öğrencileri tarafından nasıl algılandığının belirlenmesi amaçlanmıştır. Bu amaç doğrultusunda; öğrencilerin Hoca Ahmed Yesevi'ye ilişkin geliştirdikleri metaforlar ve çizdikleri resim/karikatürler incelenmiştir. Nitel araştırma deseninde gerçekleştirilen araştırmanın çalışma grubunu 2015-2016 eğitim öğretim bahar döneminde Ankara ili Mamak ilçesinde öğrenim gören 237 altıncı ve yedinci sınıf öğrencisi oluşturmaktadır. Katılımcılardan elde edilen verilerin çözümlenmesinde ve yorumlanmasında içerik analizi kullanılmıştır. Araştırma sonucunda katılımcıların, Hoca Ahmed Yesevi'yi; "bilgi sağlayan, öğüt veren", "yol gösteren, aydınlatan”, "doğruyu gösteren, fayda sağlayan" ve "iz bırakan, değerli olan" şeklinde algıladıkları görülmektedir.

Anahtar Kelimeler: Hoca Ahmed Yesevi, Sosyal bilgiler, Ortaokul, Metafor, Nitel araştırma.

\footnotetext{
* Bu çalışma 01-04 Aralık 2016, tarihinde 2016 yılı Hoca Ahmed Yesevi Yılı Anısına Antalya'da düzenlenen Uluslararası Türk Dünyası Eğitim Bilimleri ve Sosyal Bilimler Kongresinde Sözlü Bildiri olarak sunulmuştur.

${ }^{1}$ Yrd. Doç. Dr., Gazi Üniversitesi Gazi Eğitim Fakültesi, Türkçe ve Sosyal Bilimler Eğitimi Bölümü. E mail: bahadır@gazi.edu.tr

${ }^{2}$ Doç. Dr., Gazi Üniversitesi Gazi Eğitim Fakültesi, Türkçe ve Sosyal Bilimler Eğitimi Bölümü. E mail: akbaba@gazi.edu.tr Türkçe ve Sosyal Bilimler Eğitimi

${ }^{3}$ Yüksek Lisans Öğrencisi, Milli Eğitim Bakanlığı. E mail: gulbudakburcu@gmail.com
} 


\section{Giriş}

Ünlü tarihi şahsiyetlerin kişilik ve fikirlerinin yaşadıkları topluma hatta tüm insanlığa sağladığı katk1, günümüz eğitim sistemleri içerisinde yer almaktadır. Eğitim sistemleri, ünlü şahsiyetlerin insanlığa sağladığı katkıyı okul çatısı altındaki öğrencilere aktarmakta, onları örnek alınacak birer şahsiyet olarak göstererek, insanlığa yapmış oldukları katkının gelecek nesillerde de devam etmesini hedeflemektedir. Bu bağlamda, Türkiye Cumhuriyeti eğitim sisteminde yer alan ders müfredatları, gerek kendi geçmişine ait olan ünlü şahsiyetlerin gerekse yabancı şahsiyetlerin kişilik özellikleri ve insanlığa sağladıkları faydalara yer vermekte, bunların öğrencilere kazandırılmasını amaçlamaktadır. Hasan (2009) "son zamanlarda ecdadın bizlere bıraktığı zengin, manevi, medeni ve edebi-tasavvufi mirasa merak artmıştır” diyerek yukarıdaki görüşü desteklemektedir. Ona göre özellikle Türk-İslam medeniyetinde silinmez iz bırakan kimselerin ortaya koymuş oldukları eserleri okuyup öğrenmek, onları asıl manasıyla telkin etmek gerekmektedir. Bu bağlamda asırlardır Türk milletinin manevi dünyasında yüksek makamlara taht kurmuş Hoca Ahmed Yesevi'nin hayatını, eserlerini ve düşüncesini anlamayı, bunlardan faydalanmayı ve bu durumu gelecek kuşaklara aktarmayı görev edinmek, bu mirasın devamlılığı için oldukça önemlidir. Ancak Hoca Ahmed Yesevi'yi tanımadan kasıt, sadece onun hayatı, şahsiyeti ve eserleri hakkında bilgi sahibi olmak değildir. Onu tanımak aynı zamanda halkı eğitirken takip ettiği metotları ve bir eğitimci olarak sahip olduğu nitelikleri anlamak, bilmektir. Çünkü $O$, halkı eğitirken, Arapça ve Farsçayı çok iyi bilmesine rağmen söylemlerinde Türkçeyi tercih etmiş yani halk arasında yaygın olan bir üslubu kullanmıştır. Bu durum, örnek bir pedagojik davranış olarak görülmektedir (Tosun, 2000).

"Pir-i Türkistan", "Hazret-i Türkistan”, Hazret-i Sultan”, "Hace Ahmed”, “Kul Hace Ahmed" gibi farklı isimlerle tanınan Ahmed Yesevi'nin soybağı Hz. Ali'nin oğlu Muhammed Hanefiyye kadar ulaşmaktadır. Soyu Hz. Fatıma'ya dayanmadığı için, Seyyid olmayan Ahmed Yesevi'nin babası Hace İbrahim, annesi Ayşe Hanımdır (Ayvallı, 1997; Çubukçu, 1995). Doğum tarihi belli olmayan Ahmed Yesevi, bugünkü Kazakistan sınırları içinde kalan Çimkent yakınındaki Sayram kasabasında doğmuştur. Pek küçük yaştayken annesini, henüz yedi yaşındayken de babasını kaybeden Ahmed Yesevi, ablasıyla birlikte Yesi (bugünkü adıyla Türkistan) şehrine gitmiş ve orada ilk tahsiline başlamıştır. Yaşı küçük olmasına karşın bazı tecellilere mazhar olması, üstün yetenekler ortaya koyması ile çevresinde dikkat toplamıştır. Anlatılanlara göre, yedi yaşında Hazreti Hızır'ın delaletine nail olan Ahmed Yesevi, Yesi'de Arslan Baba'ya bağlanarak sofilik kültürünü almış, ilim ve irfanını artırmak için Yesi'den Buhara'ya giderek, orada devrin ileri gelen bilginlerinden olan Şeyh Yusuf el- 
Hemedani'ye bağlanmıştır. Ancak daha önce kendine verilen Türkistan'1 uyandırma vazifesinden dolayı Buhara'dan ayrılmak durumunda kalmış, tekrardan Yesi’ye gitmiş ve ömrünün son yıllarına kadar burada yaşamıştır (Bice, 2015; Çakan, 2005; Eraslan, 1995; Tosun, 2000; Y1lmaz, 1997).

Ahmed Yesevi, yetiştirdiği binlerce talebenin her birini farklı memleketlere göndererek, İslam dininin doğru bir şekilde aktarılıp onun doğru bir biçimde yayılmasına katkı sağlamıştır. Onun yönlendirdiği talebelerinden bazıları, sonradan Moğolların katliamlarından kaçıp kurtularak Anadolu'yu yurt edinmişlerdir. Böylelikle Yesevi'nin inancı Anadolu'da tanınmış ve buranın Müslüman Türklere yurt olmasına katkı sağlamıştır (Ayvallı, 1997). Ahmed Yesevi'ye ait; eğitimini en üst seviyede tamamlaması, eğitimi sırasında aldığ bilgileri topluma ve öğrencilerine aktarması, etrafına topladığı öğrencileri en üst seviyede eğiterek farklı ülkelerin çeşitli bölgelerine göndererek eğitim öğretim faaliyetlerinin yaygınlaştırılarak sürdürülmesi, eğitime tabi tuttuğu toplumların ve bireylerin bütün özelliklerini tanıyarak onların seviyesine uygun eğitim metotları geliştirmesi, her şeyden önemlisi de içinde bulunduğu ve eğitmeyi hedeflediği kitlenin anlayacağı dili kullanmayı tercih etmesi, hedef kitlesi arasında dil, din, 1rk ve cinsiyet gibi konularda ayrım gözetmeyerek farklılıklara saygı duyması, insan haklarına saygılı ve adaletli davranması, toplumun arasındaki ayrılık unsurlarının sebeplerini bulup, çözüm önerileri ile birlik ve beraberliği sağlamayı hedeflemesi gibi davranışlar onun örnek alınması gereken özellikleri arasındadır (Çoban, 2016).

Geniş bir coğrafyanın İslam dini ile tanışmasını sağlayan ve kültürlerin etkileşimi ve yakınlaşması açısından son derece önemli bir şahsiyet olan Hoca Ahmed Yesevi, "geçmişte iyi çalışmalarıyla insanlık için model oluşturmuş kişilerin anılması" düşüncesinden hareketle UNESCO Türkiye Milli Komisyonu tarafından sunulmuş ve kabul edilmiş öneriye göre vefaatının 850. yılında, 2016 yılında dünya çapında çeşitli etkinliklerle anılmıştır.

Ahmed Yesevi'nin yukarıda bahsedilen özelliklerinin örnek alınması ve gelecek kuşaklara rol model bir şahsiyet olarak aktarılmasında şüphesiz öğretim programlarının payı büyüktür. Bu bağlamda, sosyal bilgiler öğretim programında yazılı ve sözlü malzemenin düzenlenmesine, yorumlanmasına dayanan ve bir kişinin yaşamını konu alan biyografilerin sosyal bilgiler öğretiminde etkili bir araç olarak kullanılabildiği bilinmektedir (Öztürk ve Otluoğlu, 2005).

Biyografi davranış, hayat hikâyeleri ve ortaya koydukları eserlerle toplumu pozitif olarak etkileyen insanlar hakkında yazılan edebi tür olarak tanımlamaktadır ve biyografilerin konusunu, insanların hayat hikâyelerinin tümü veya bir kısmı, eserleri, yapmış oldukları çalışmalar vb. oluşturmaktadır. Sosyal bilgiler dersinde biyografi kullanımındaki amaç; 
toplumların kaderine yön vermiş, kayda değer icatlar ortaya koymuş, liderlik özelliği ile insanlığa yol gösteren ünlü şahısların hayatlarından yararlanmaktır (Kaymakçı ve Er, 2012). Ancak, şahısların hayat hikâyelerini yansıtan bir biyografiyi kullanmadan önce öğrencilerin o biyografi hakkındaki algılarının ortaya konması hem biyografinin öğretimine hem de biyografi ile kazandırılmak istenenlerin kalıcılığına katkı sağlayacaktır. Bu bağlamda araştırmada; UNESCO'nun 2016 yılı uluslararası etkinliklerle kutlama programında ve sosyal bilgiler 6 ve 7. sınıf öğretim programında yer alan Türk-İslam mütefekkirlerinden Hoca Ahmed Yesevi’nin altıncı ve yedinci sınıf öğrencileri tarafindan nasıl algılandığının belirlenmesi amaçlanmıştır.

\section{YÖNTEM}

$\mathrm{Bu}$ çalışmada ortaokul altı ve yedinci sınıf öğrencilerinin, sosyal bilgiler altı ve yedinci sınıf öğretim programında yer alan Türk-İslam mütefekkirlerinden Hoca Ahmed Yesevi'yi nasıl algıladıklarını belirlemek amacıyla; metaforlar aracılığıyla veri toplama ve doküman incelenmesinden oluşan nitel araştırma teknikleri birlikte kullanılmıştır.

\section{Çalışma Gurubu}

Araştırmanın çalışma gurubu, 2015-2016 eğitim-öğretim y1lı bahar döneminde Ankara ili, Mamak ilçesinden amaçsal örnekleme yöntemlerinden olan kolay ulaş1labilir örnekleme yöntemiyle seçilmiş olan ortaokuldaki toplam 237 (124 kız - 113 erkek), 6 ve 7. sınıf ${ }^{4}$ öğrencisinden oluşmaktadır. Çalışmanın 8.sınıf öğrencilerine uygulanamayış nedeni, öğrencilerin Temel Eğitimden Ortaöğretime Geçiş (TEOG) sınavına hazırlanıyor olmaları ve araştırmanın uygulanma zamanı ile bu sınavın uygulanma tarihinin birbirine yakın zamana denk gelmesinden dolayıdır. Çalışmanın kolay ulaşılabilir örnekleme yöntemine uygun olarak seçilmesi, araştırmacıların (3. yazar) okulun idari personeli ile önceden tanışıyor olmasıdır. Alan yazında araştırma yapılacak örnekleme grubuna kolay ulaşılabilirliğin, yani örneklem grubunun uygunluğunun, araştırmanın uygulama sürecini zaman, para ve mekân bakımından ekonomikleştirdiği çeşitli araştırmacılar (Merriam, 2013; Patton, 2002; Yıldırım ve Şimşek, 2006) tarafindan dile getirilmektedir.

\section{Veri Toplama Araçları}

1. Metaforlar Aracılığıyla Veri Toplama Formu: Katılımcıların sosyal bilgiler 6 ve 7. sınıf öğretim programında yer alan Hoca Ahmed Yesevi’ye ilişkin algılarını ortaya koymak

\footnotetext{
${ }^{4} 2016$ yılının, Hoca Ahmed Yesevi yılı ilan edilmesi münasebetiyle çalışma yapılan okuldaki sosyal bilgiler öğretmenlerinin 6 ve 7. Sınıf öğrencilerini, Hoca Ahmed Yesevi ve eserleri konusunda bilgilendirdiği bilinmektedir.
} 
için çeşitli araştırmacılar (Aydın, 2010; 2011; Çetin, Kılcan, Güneş, ve Çepni, 2015; Kılcan ve Akbaba, 2013; 2014; Kılcan ve Çepni, 2015; Saban, 2008a; 2008b; 2009) tarafından kullanılmış olan metaforlar ile veri toplama aracı kullanılmıştır.

2. Doküman İncelemesi: Araştırmada veri toplama amacıyla kullanılan metafor formuna ek olarak, katılımcıların Hoca Ahmed Yesevi ile ilgili olarak çizdikleri görsellerden yararlanılmıştır. Görseller öğrencilerin duygu ve düşüncelerini yansıtan, yorumlama ve çözüm sunma becerilerini de ortaya çıkaran önemli materyaller olarak görülmektedir (Ersoy ve Türkkan, 2010). Literatür, görsellerin tek başlarına nitel bir araştırmada kullanılabileceği gibi yine nitel araştırmada kullanılabilecek görüşme, gözlem ve doküman incelemesi gibi tekniklerle de kullanılabileceğinden bahsetmektedir (Yıldırım ve Şimşek, 2006).

\section{Verilerin Toplanması}

Verilerin toplanması aşamasında her bir öğrenciye, Hoca Ahmed Yesevi ile ilgili form verilmiştir. Uygulamaya geçilmeden önce araştırmacılar (3. yazar) araştırmanın hangi amaçla yapıldığı ve çalışmanın nasıl yapılacağı konusunda katılımcıları bilgilendirmiştir. Daha sonra uygulamaya başlanmıştır. Katılımcılarca oluşturulan metaforlar, metaphor gerekçelerine gerekçeye uygun çizilen görsel bir alan uzmanı (1. yazar) eşliğinde incelenmiş ve benzer ve farklı görsel oluşturanlar ile hiç görsel oluşturmayanlar belirlenmiştir. Bu belirlemelerde; görsellerin katılımcılarca özenle çizilip çizilmediği, anlaşılabilirliği, üretilen metaforun gerekçesini yansıtıp yansıtmadığı vb. etkenler araştırmacılarca (1. ve 2. yazar) görüş birliği sağlanarak yapılmıştır.

\section{Verilerin Analizi ve Yorumlanması}

$\mathrm{Bu}$ aşamada hem mecazlar yoluyla toplanan verilerin hem de yarı yapılandırılmış görüşme formu ile toplanan verilerin çözümlenmesi ve yorumlanması hakkında değerlendirmeler yapılmıştır.

Mecazlar Yoluyla Toplanan Verilerin Çözümlenmesi ve Yorumlanması

Uygulama sonrasında elde edilen verilerin çözümlenmesinde içerik analizi kullanılmıştır. Büyüköztürk, Kılıç-Çakmak, Akgün, Karadeniz ve Demirel (2010) tarafından içerik analizi, bireylerin davranışları hakkında dolaylı yollarla çalışmaya firsat sunan bir teknik olarak tanımlanmaktadır. Buna ek olarak verilerin analizi ve yorumlanması Saban'dan (2009) yararlanılarak beş aşamada yapılmıştır. Bunlardan Kodlama ve Ayıklama Aşamasında; katılımcılardan elde edilen veriler rakamlar verilerek kodlanmış ve bu formlarda, metaforun yer aldığı ancak gerekçesine yer verilmeyen 95 adet form elenerek değerlendirme dışı 
bırakılmıştır. Örnek Metafor Derleme Aşamasında; Saban, (2009) tarafından kullanılan "metafor analizi" ve Yıldırım ve Şimşek'in (2006) belirttiği “içerik analizi” metotları kullanılarak üretilen her metafor ayrıştııılmıştır. Böylelikle katılımcıların üretiikleri metaforlar tekrar gözden geçirilerek benzeyen, benzetilen ve benzeyen ve benzetilen arasındaki bağ değerlendirilmiştir. Bu değerlendirme sonucu zayıf yapı imgelerden oluşan formlar ayıklanarak, uygulama öncesi Hoca Ahmed Yesevi ile ilgili 237 katılımcıdan 142 adet geçerli metafor elde edilmiştir. Kategori Oluşturma Aşamasında; katılımcılar tarafından Hoca Ahmed Yesevi'ye ilişkin üretilen metaforlar, gerekçelerine göre kategorilere ayrılmıştır. Geçerlik ve Güvenirlik Aşamasında; Bu aşamada, ulaşılan kavramsal kategorilerde yer alan metaforların, kavramsal kategorileri temsil edebilirliğini belirlemek amacıyla araştırmacıların ayrı ayrı görüşlerine yer verilmiştir. Araştırmacılar tarafından ayrı ayrı oluşturulan metafor listeleri ile kavramsal kategorileri içeren listeler Miles ve Huberman'1n (1994) görüş birliği/görüş birliği+görüş ayrılığı formülü göz önünde bulundurularak incelenmiştir. Daha sonra bir uzman ile (1. yazar) diğer uzmanın (3.yazar) yaptı̆̆ eşleştirmeler sonucu oluşan kategoriler karşılaştırılmış ve \%98 güvenirlik saptanmıştır. Bu değerler, Saban'ın (2009) bu türlü nitel araştırmalarda farklı değerlendiricilerin ortaya koydukları değerlendirmeler arasındaki uyumun \%90'ın üstünde olduğu durumlarda istenilen düzeyde bir güvenirliğe sahip olduğu görüşüyle örtüşmektedir. Elde Edilen Verilerin PC Ortamına Aktarılması; Bu aşamada kategorilere ayrılan metaforlar, bulundukları kategoriyi temsil eden katılımcıların sayısı (f) ve yüzdesi (\%) hesaplanmıştır. Metafor gerekçelerine ait aynen alıntıların raporlaştırılmasında katılımcılara ait kodlamalar (Ö1-Ö5-Ö36) kullanılmıştır.

\section{BULGULAR}

Tablo 1. Katılımcıların Hoca Ahmed Yesevi’ye Yönelik Geliştirdikleri Metaforlar (Mecazlar)

\begin{tabular}{llccclcr}
\hline & Metafor (Mecaz) & $\mathbf{f}$ & $\mathbf{\%}$ & Metafor(Mecaz) & f & \% \\
\hline 1 & A ğaç & 1 & 0.70 & 25 & İlmihal & 2 & 1.40 \\
\hline 2 & Akıllı Tahta & 1 & 0.70 & 26 & İmam & 2 & 1.40 \\
\hline 3 & Ampül & 1 & 0.70 & 27 & İnternet & 1 & 0.70 \\
\hline 4 & Anahtar & 1 & 0.70 & 28 & Kitap & 37 & 25.90 \\
\hline 5 & Ansiklopedi & 3 & 2.10 & 29 & Kuranı Kerim & 2 & 1.40 \\
\hline 6 & Araci / İletken & 1 & 0.70 & 30 & Kütüphane & 3 & 2.10 \\
\hline
\end{tabular}




\begin{tabular}{|c|c|c|c|c|c|c|c|}
\hline 7 & Arama Motoru & 3 & 2.10 & 31 & Lamba & 1 & 0.70 \\
\hline 8 & Ateş & 1 & 0.70 & 32 & Melek & 1 & 0.70 \\
\hline 9 & Beyin & 1 & 0.70 & 33 & Meşale & 1 & 0.70 \\
\hline 10 & Bilgisayar & 6 & 4.20 & 34 & Mum Iş1 & 9 & 6.30 \\
\hline 11 & Bilim İnsanı & 1 & 0.70 & 35 & Navigasyon & 1 & 0.70 \\
\hline 12 & Çikolata & 1 & 0.70 & 36 & Öğretmen & 6 & 4.20 \\
\hline 13 & Denize Atılan Bir Taş & 1 & 0.70 & 37 & Peygamber & 2 & 1.40 \\
\hline 14 & Din Kitab1 & 3 & 2.10 & 38 & P1rıltılı Bir Elmas & 1 & 0.70 \\
\hline 15 & Din Öğretmeni & 2 & 1.40 & 39 & Postac 1 & 1 & 0.70 \\
\hline 16 & Dini Kitap & 2 & 1.40 & 40 & Pusula & 3 & 2.10 \\
\hline 17 & Einstein & 1 & 0.70 & 41 & Reklam & 1 & 0.70 \\
\hline 18 & Elmas & 1 & 0.70 & 42 & Saat & 4 & 2.80 \\
\hline 19 & Evliya & 1 & 0.70 & 43 & Sözlük & 5 & 3.50 \\
\hline 20 & Google & 4 & 4.20 & 44 & Telefon & 1 & 0.70 \\
\hline 21 & Güneş & 7 & 4.90 & 45 & $\begin{array}{l}\text { Yağmur Dolu } \\
\text { Bulutlar }\end{array}$ & 1 & 0.70 \\
\hline 22 & Harita & 3 & 2.10 & 46 & Y1ld1z & 1 & 0.70 \\
\hline 23 & Hoş Kokulu Bir Çiçek & 1 & 0.70 & 47 & Yönerge & 1 & 0.70 \\
\hline \multirow[t]{2}{*}{24} & Iş1k & 6 & 4.20 & 48 & Zekâ Küpü & 1 & 0.70 \\
\hline & & & & & Toplam & 142 & 100 \\
\hline
\end{tabular}

Tablo 1'e bakıldığında, katılımcılar Hoca Ahmed Yesevi'ye yönelik 48 adet metafor ürettikleri görülmektedir. Üretilen metaforların yirmi yedi tanesi bir katılımcı tarafından üretilmiştir. Kalan 21 metafor ise 2-37 katılımcı tarafindan temsil edilmektedir. Metafor 
başına düşen ortalama katılımcı sayısı yaklaşık olarak 2,9'dur. Hoca Ahmed Yesevi'ye ilişkin metaforların frekans dağılımına bakıldığında en sık kullanılanlar arasında "kitap" (f:37), "mum 1şı̆̆ı" (f:9) ve "güneş" (f:7) gelmektedir.

Tablo 2. Katılımcıların Hoca Ahmed Yesevi'ye Yönelik Sahip Oldukları Metafor (Mecaz)

Kategorileri

\begin{tabular}{llcc}
\hline & & Metafor & Toplam \\
S.N. Kategori & Metafor (Mecaz) & Sayısı & Metafor
\end{tabular}

\begin{tabular}{|c|c|c|c|c|}
\hline 1 & $\begin{array}{l}\text { Bilgi } \\
\text { Sağlayan, } \\
\text { Öğüt Veren }\end{array}$ & $\begin{array}{c}\text { Akıllı Tahta, Ansiklopedi, Aracı / } \\
\text { İletken, Arama Motoru, Beyin, } \\
\text { Bilgisayar, Bilim İnsanı, Denize } \\
\text { Atılan Bir Taş, Din Kitabı, Dini } \\
\text { Kitap, Einstein, Evliya, Google, } \\
\text { İlmihal, İmam, İnternet, Kitap, } \\
\text { Kütüphane, Mum Işı̆̆ı, Öğretmen, } \\
\text { Peygamber, Postacı, Reklam, Sözlük, } \\
\text { Telefon, Zekâ Küpü }\end{array}$ & 26 & 89 \\
\hline 2 & $\begin{array}{l}\text { Yol Gösteren, } \\
\text { Aydınlatan }\end{array}$ & $\begin{array}{c}\text { Ampul, Anahtar, Din Kitabı, Güneş, } \\
\text { Harita, Işık, Kitap, Kur'an-1 Kerim, } \\
\text { Lamba, Meşale, Mum Işığı, } \\
\text { Navigasyon, Öğretmen, Pusula, } \\
\text { Yağmur Dolu Bulutlar, Yıldız, } \\
\text { Yönerge }\end{array}$ & 17 & 38 \\
\hline 3 & $\begin{array}{l}\text { Doğruyu } \\
\text { Gösteren, } \\
\text { Fayda } \\
\text { Sağlayan }\end{array}$ & $\begin{array}{l}\text { Ağaç, din kültürü öğretmeni, güneş, } \\
\text { Kuran-1 kerim, melek, pusula, saat }\end{array}$ & 7 & 10 \\
\hline 4 & $\begin{array}{l}\text { İz bırakan, } \\
\text { Değerli Olan }\end{array}$ & $\begin{array}{l}\text { Ateş, Çikolata, Elmas, Hoş Kokulu } \\
\text { Bir Çiçek, Pırıltılı Bir Elmas }\end{array}$ & 5 & 5 \\
\hline
\end{tabular}

Tablo 2'ye bakıldığında, katılımcıların Hoca Ahmed Yesevi'ye yönelik ürettikleri metaforlar benzer özellikleri bakımından 4 kategori altında toplanmıştır. 


\section{Kategori: Bilgi Sağlayan, Öğüt Veren}

Tablo 2'de, "bilgi sağlayan, ögüt veren” kategorisinin 26 metafor ve 89 katılımcının (\%62.30) ürettiği metafordan oluştuğu görülmektedir. Kategorideki en sik kullanılan metaforlar "kitap" (f:35), "bilgisayar” (f:6) ve “öğretmen” (f:8)'dir. Aşağıda katılımcıların "bilgi sağlayan, öğüt veren” kategorisini neden geliştirdiklerine yönelik gerekçelerine ve katılımcılar tarafından geliştirilen metafora ait görsele yer verilmiştir.

“Hoca Ahmed Yesevi kitap gibidir. Çünkü kitaplar bize bilgi verir. Ahmed Yesevi de bilgin bir kişidir biz ona bir şey sorduğumuzda cevabını onda bulabiliriz.” (Ö, 106).

“ Hoca Ahmed Yesevi bilgisayar gibidir. Çünkü bilgisayara sorulan her sorunun cevabını bulabiliriz. Bu hocaya sorulan soruların cevabını buluyoruz ...” (Ö, 173).

"Hoca Ahmed Yesevi google gibidir. Çünkü her şeyi bilir...” (Ö,141).

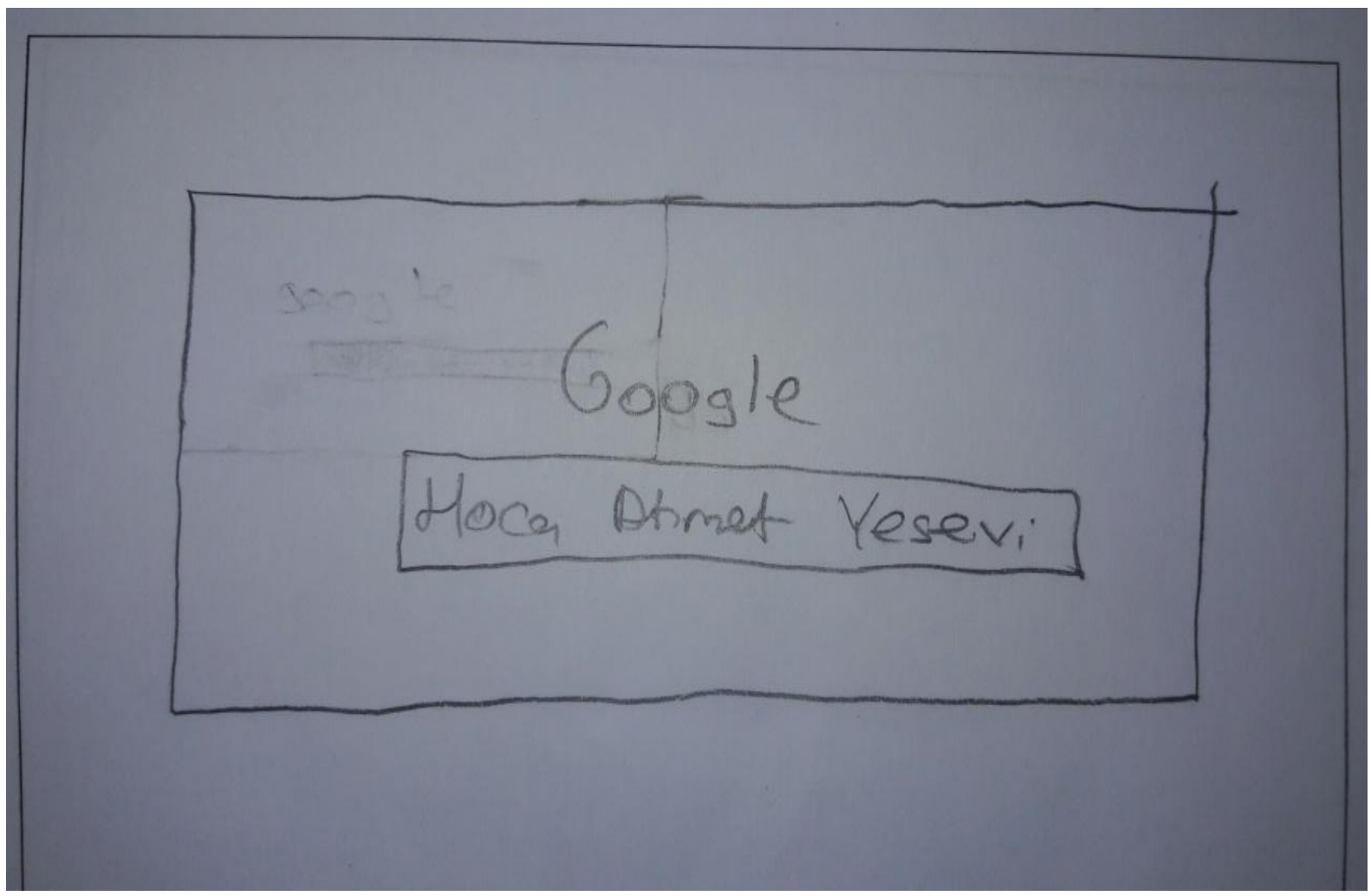

"Hoca Ahmed Yesevi ilmihal gibidir. Çünkü içinde her türlü dini bilgileri bulunduruyor ve bilgi almamıza neden oluyor." (Ö, 13). 


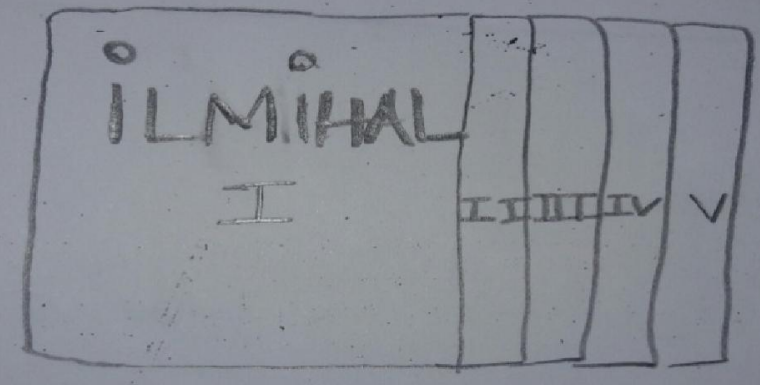

\section{Kategori: Yol Gösteren, Aydınlatan}

Tablo 2'de, “yol gösteren, aydınlatan” kategorisinin 17 metafor ve 38 katılımcinın (\%26.60) ürettiği metafordan oluştuğu görülmektedir. Kategorideki en sik kullanılan metaforlar "mum 1şığı" (f:7), "güneş" (f:6) ve "1şık” (f:6)'dır. Aşağıda katılımcıların "yol gösteren, aydınlatan" kategorisini neden geliştirdiklerine yönelik gerekçelerine ve katılımcılar tarafından geliştirilen metafora ait görsele yer verilmiştir.

“Hoca Ahmed Yesevi mum ışı̆̆ı gibidir. Çünkü etrafına bilgi verir, mum 1şığı gibi. Yani mum ışı̆̆ı etrafını aydınlatıyor. Ahmed Yesevi'de etrafına çeşitli bilgiler veriyor. Etrafina doğru yolu gösteriyor.” (Ö,84).

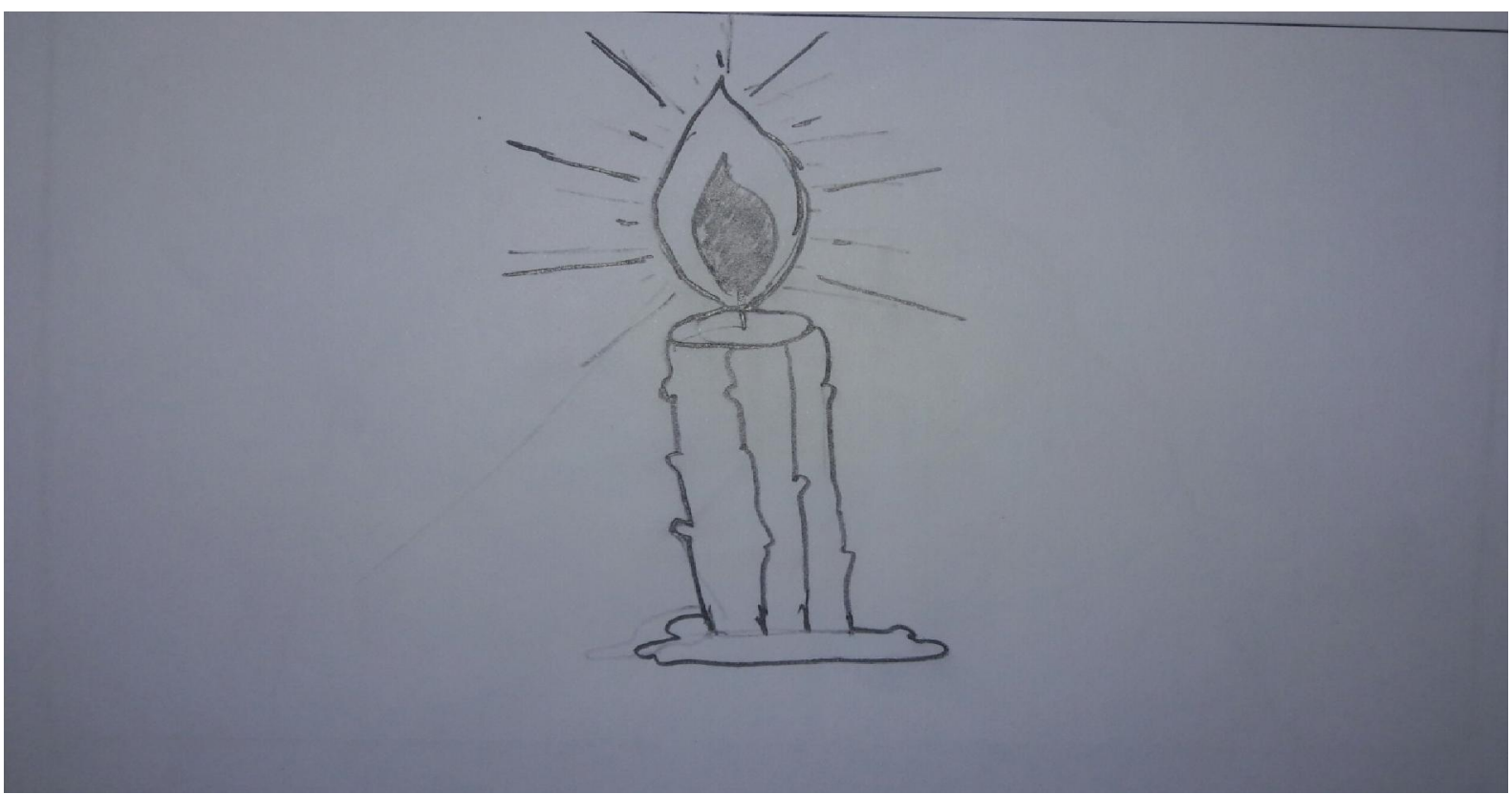

"Hoca Ahmed Yesevi ışık gibidir. Çünkü ... bir yandan ışık gibi yol gösterir her yeri aydınlatır..." (Ö,184). 


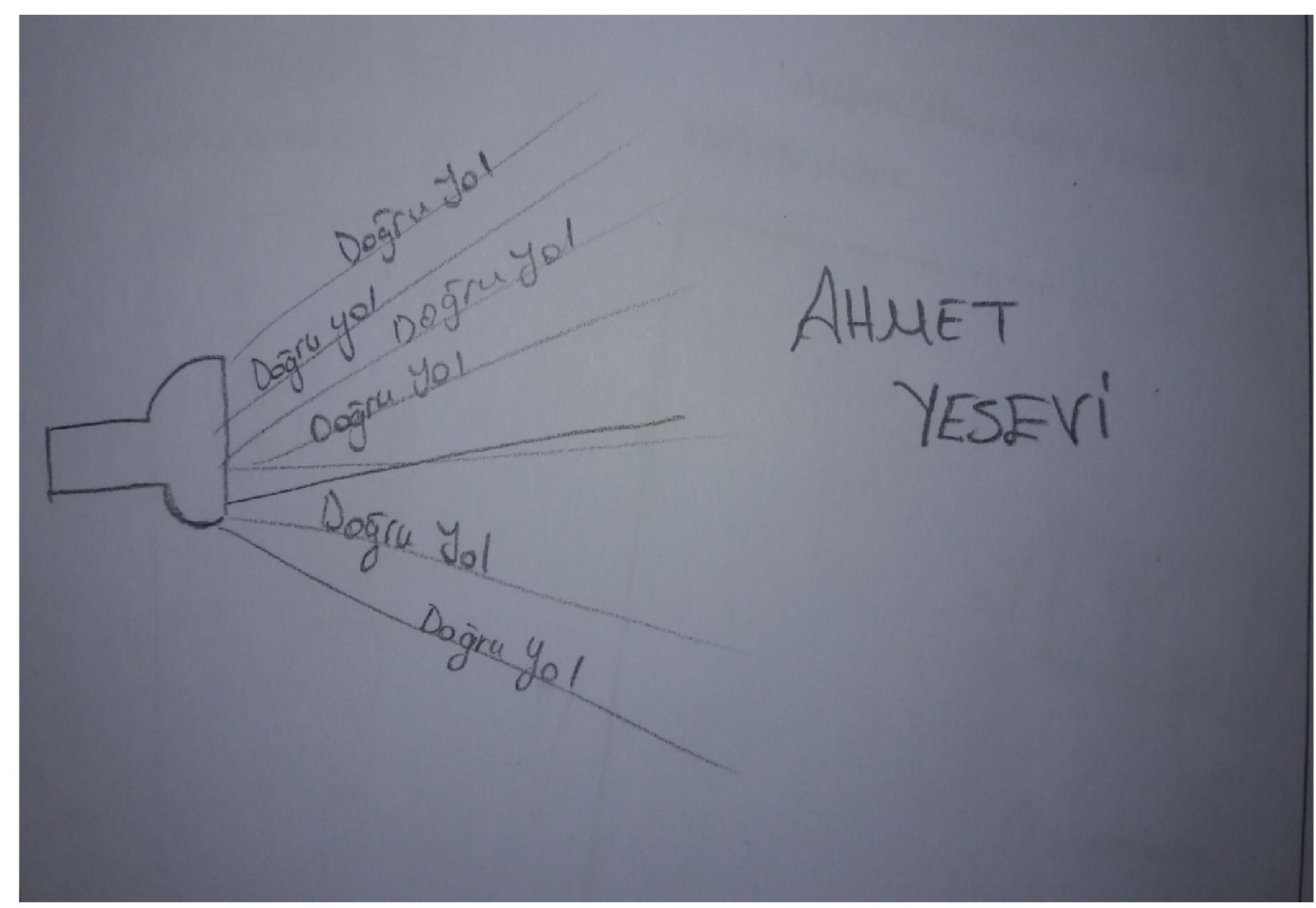

"Hoca Ahmed Yesevi navigasyon gibidir. Çünkü navigasyon aleti bize yol gösterir tarif eder. Navigasyon aleti bizi hedefe gönderir aynı şekilde Hoca Ahmed Yesevi'de bize yol gösterir." (Ö,157).

“Hoca Ahmed Yesevi güneş gibidir. Çünkü her zaman yolumuzu aydınlatır.” (Ö,227).

\section{Kategori: Doğruyu Gösteren, Fayda Sağlayan}

Tablo 2'de, “doğruyu gösteren, fayda sağlayan" kategorisinin 7 metafor ve 10 katılımcının (\%7.00) ürettiği metafordan oluştuğu görülmektedir. Kategorideki en sık kullanılan metafor "saat” (f:4)’tir. Aşağıda katılımcıların "doğruyu gösteren, fayda sağlayan” kategorisini neden geliştirdiklerine yönelik gerekçelerine ve katılımcılar tarafından geliştirilen metafora görsele yer verilmiştir.

"Hoca Ahmed Yesevi güneş gibidir. Çünkü güneşin insanlara, hayvanlara ve bitkilere faydaları vardır. Hoca Ahmed Yesevi’nin de İslam dinine faydaları vardır ...” (Ö,23). 


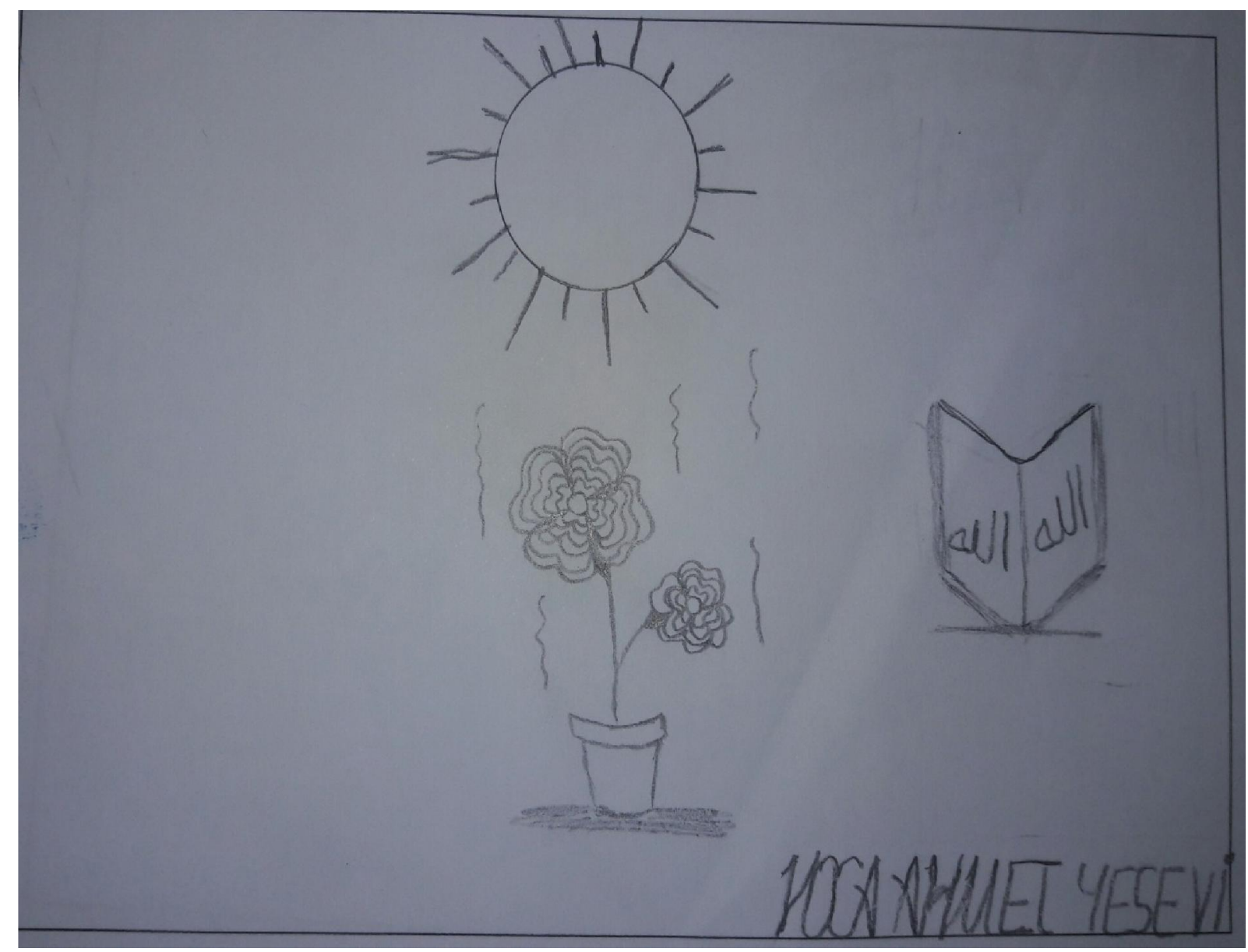

"Hoca Ahmed Yesevi saat gibidir. Çünkü doğru zamanı gösterir. Ona bakıp zamanımızı doğru kullanabiliriz.” (Ö,129).

“Hoca Ahmed Yesevi ağaç gibidir. Çünkü Hoca Ahmed Yesevi insanlara her yönüyle yardımcı olmaya çalışmış bir zattır. Ağaçlarda insanlara meyvesiyle, toprak kaymasını engellemesiyle, gölgesiyle ve daha pek çok yönüyle insanlara yardımcı olur...”(Ö,103).

\section{Kategori: İz bırakan, Değerli Olan}

Tablo 2 incelendiğinde, "iz birakan, değerli olan" kategorisinin toplam 5 metafor ve 5 katılımcı (\%3.50) şeklinde oluştuğu görülmektedir. Bu kategoride bulunan metaforların frekans dağılımlarına bakıldığında her metafor bir katılımeı tarafından temsil edilmektedir. Aşağıda katılımcıların "iz bırakan, değerli olan” kategorisini oluşturan metaforları neden geliştirdiklerine yönelik gerekçelerine ve yine aynı katılımcı tarafından geliştirdiği metafora ait görsele yer verilmiştir.

Tablo 2'de, “iz bırakan, değerli olan” kategorisinin 5 metafor ve 5 katılımcının (\%3.50) ürettiği metafordan oluştuğu görülmektedir. Kategorideki her metaphor bir katılımcıyı temsil etmektedir. Aşağıda katılımcıların “iz bırakan, değerli olan” kategorisini 
neden geliştirdiklerine yönelik gerekçelerine ve katılımcılar tarafından geliştirilen metafora ait resme / karikatüre yer verilmiştir.

"Hoca Ahmed Yesevi elmas gibidir. Çünkü... Ahmed Yesevi hem bulunmaz hem nadir bir insandır bu yüzden elmas..." (Ö,82).

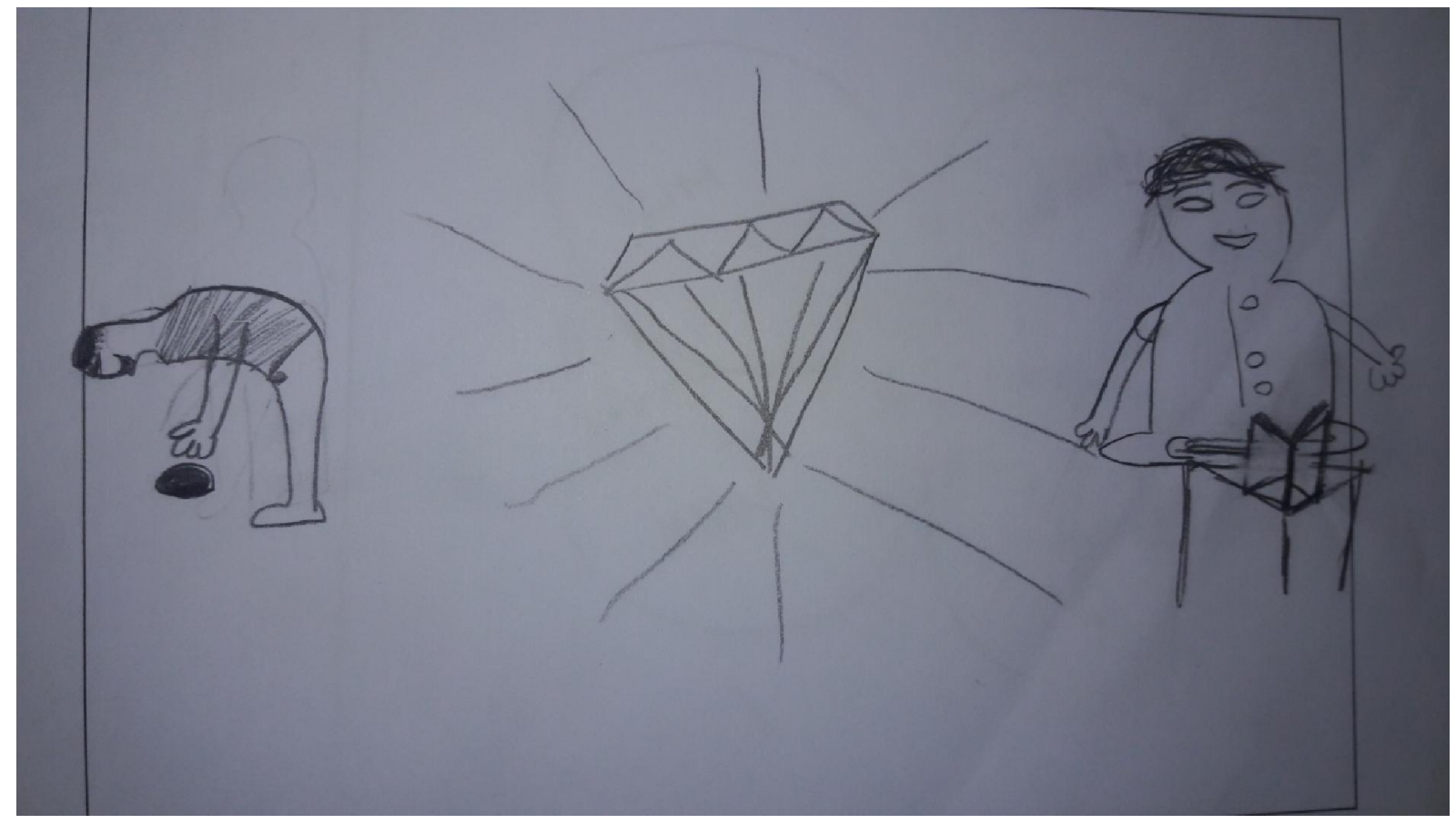

"Hoca Ahmed Yesevi çikolata gibidir. Çünkü çikolata insanların çok sevdiği bir abur cuburdur. Hoca Ahmed Yesevi'de çok sevilen bir insan olduğundan ben çikolataya

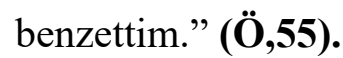

"Hoca Ahmed Yesevi ateş gibidir. Çünkü hem Hoca Ahmed Yesevi hem de ateş geçtiğii, değdiği, dokunduğu, temas ettiği her yerde az veya çok bir iz, bir bilgi bırakır." (Ö,29).

\section{Sonuç ve Tartışma}

Türk-İslam dünyasına hizmetleri dokunmuş Hoca Ahmed Yesevi’yi altıncı ve yedinci sınıf öğrencilerinin nasıl algıladıklarını ortaya koymak için yapılan bu çalışmada, katılımcılar tarafindan üretilen metaforlara, bu metaforlardan oluşturulan metafor kategorilerine ve görsellere bakıldığında; katılımcıların büyük bir çoğunluğunun Hoca Ahmed Yesevi’yi “bilgi sağlayan, öğüt veren" olarak algıladıkları görülmektedir. Katılımcılar tarafından genelde "kitap, bilgisayar, ilmihal" gibi benzetmeler yapılması ve bu benzetmelere ilişkin görseller çizmeleri Hoca Ahmed Yesevi Hakkında bilişsel bilgiye sahip olduklarının göstergesidir. Çünkü Ayvallı’ya (1997) göre Hoca Ahmed Yesevi, yetiştirdiği binlerce talebenin her birini 
farklı memleketlere göndererek, İslam dininin doğru olarak öğretilip yayılmasını sağlamıştır. $\mathrm{Bu}$ yönü onun, bir ilmihal gibi, İslam dininin doğru yaşanması için yol gösterici olduğunun göstergesidir.

Bir başka sonuç ise; katılımcıların yine büyük bir bölümünün Hoca Ahmed Yesevi'yi “yol gösteren, aydınlatan” olarak algıladıklarıdır. Hoca Ahmed Yesevi’yi bu şekilde algılayan katılımcılar genelde “mum 1şı̆̆ı, 1şık” gibi benzetmeler yapmışlardır. Bu benzetmeler, Hoca Ahmed Yesevi'nin çevresindeki insanlara ve talebelerine bilgi verdiğinin, onları her manada doğru yola sevk ettiğinin katılımcılar tarafından bilindiğinin göstergesidir. Çünkü Çoban’a (2016) göre Hoca Ahmed Yesevi eğitimini en üst seviyede tamamlamış, eğitimi sırasında aldığı bilgileri topluma ve öğrencilerine aktarmış, etrafına topladığı öğrencileri en üst seviyede eğiterek onları doğru yola sevk etmiş bir şahsiyettir. Bu durum katılımcıların, Hoca Ahmed Yesevi ve yaptıkları hakkında bilişsel düzeyde bilgiye sahip olduklarının göstergesidir.

Çalışmaya ait diğer bir sonuç ise Hoca Ahmed Yesevi'nin katılımcılar tarafından “iz bırakan, değerli olan” olarak algılanmasıdır. O’nu, bu şekilde algılayan katılımcılar "elmas, ateş, çikolata" gibi benzetmeler yaparak onun yeri doldurulamayacak izler bıraktığını ve elmas gibi çok değerli olduğunu belirtmektedirler. Bu durum Hoca Ahmed Yesevi hakkında Hasan'ın (2009) “O, özellikle Türk-İslam medeniyetinde silinmez iz bırakan, Türk milletlerinin maneviyatında yüksek makam etmiş ediplerdendir" şeklindeki ifadesiyle de örtüşmektedir. Katılımcıların Hoca Ahmed Yesevi’yi “iz bırakan, değerli olan” olarak algılamaları da Yesevi hakkında bilişsel bilgiye sahip olduklarının göstergesidir.

Ayrıca sosyal bilgiler 6 ve 7. sınıf öğretim programında Hoca Ahmed Yesevi hakkında çok kısa bir bilgi yer almasına karşın, uygulama yapılan okuldaki sosyal bilgiler öğretmenleri tarafından, 2016 yılı Hoca Ahmed Yesevi’yi anma y1lı münasebetiyle yapılan etkinliklerin (Hoca Ahmed Yesevi ve eserleri hakkında bilgi verme, sinevizyon gösterisi vs.) öğrencilerin Hoca Ahmed Yesevi algılarına ve bilişsel bilgi düzeylerine olumlu şekilde katkı sağladığını göstermektedir.

Çalışmanın sonuçlarına bağlı olarak şu önerilerde bulunulabilir; Hoca Ahmed Yesevi gibi ünlü tarihi şahsiyetler hakkında ortaokul öğrencilerinin algılarını tespit eden çalışmalar yapılabilir. Yapılan bu çalışmalar sosyal bilgiler öğretiminde yer alan biyografilerin öğretiminde kullanılabilir. 


\section{References / Kaynaklar}

Aydın, F. (2010). Ortaöğretim öğrencilerinin coğrafya kavramına ilişkin sahip oldukları metaforlar, Kuram ve Uygulamada Ĕgitim Bilimler Dergisi, 10(3), 1313-1322.

Aydın, F. (2011). Üniversite öğrencilerinin "çevre” kavramına ilişkin metaforik algıları, Doğu Coğrafya Dergisi, 16(26), 25-44.

Ayvallı, R. (1997). Pakistan'da neşredilen bir esere göre Ahmed Yesevi, Türkiyat Araştırmaları Dergisi, Say1 3, 5-10.

Bice, H. (2015). Divan-ı Hikmet (Genişletilmiş 5. Baskı), Ankara: Türkiye Diyanet Vakfı.

Büyüköztürk, Ş.; Kılıç-Çakmak, E.; Akgün, Ö. E.; Karadeniz, Ş. \& Demirel, F. (2010). Bilimsel araştırma yöntemleri. (7. Bask1). Ankara: Pegem.

Çakan, V. (2005). Hoca Ahmed Yesevi ve Divân-1 Hikmet, Millî Folklor, Say1 68, 201-207.

Çetin, T.; Kılcan, B.; Güneş, C. \& Çepni, O. (2015). Examining secondary school students' perceptions of the concept of migration: A Qualitative study, International Journal of Education, 7(3), 97-120.

Çoban, H. (2016). Sosyal bilgiler ĕgitimi ve öğretiminde öğretmen rol modeli olarak Ahmed Yesevi, Uluslararası sosyal bilgiler eğitimi sempozyumu bildiriler kitabı içinde, (ss.513-52). Denizli: Pamukkale Üniversitesi.

Çubukçu, İ. A. (1995). Ahmed Yesevi ve Düşüncesi, Erdem Atatürk Kültür Merkezi Dergisi Hoca Ahmed Yesevî Özel Sayısl, 7(21), 821-831.

Eraslan, K. (1995). Ahmed-i Yesevî, Erdem Atatürk Kültür Merkezi Dergisi Hoca Ahmed Yesevî Özel Sayısı, 7(21), 799-819.

Ersoy, A. F. \& Türkkan, B. (2010). İlköğretim öğrencilerinin çizdikleri karikatürlere yansıttıkları sosyal ve çevresel sorunların incelenmesi. Eğitim ve Bilim, 35(156), 96-109.

Hasan, N. (2009). Yeseviliğe dair bazı kaynak eserler hakkında, Turkish Studies, 4(2), 618-633.

Kaymakçı S. \& Er, H. (2012). Sosyal bilgiler öğretiminde biyografi kullanımı. İçinde M. Safran, (Ed.), Sosyal Bilgiler Öğretimi. (2. Baskı). Ankara: Pegem.

Kılcan, B. \& Çepni, O. (2015). A qualitative examination of the perceptions of the eight grade students regarding the concept of environmental pollution, J. Int. Environmental Application \& Science, 10(2), 239-250.

Kılcan, B. \& Akbaba, B. (2013). Sosyal bilgiler öğretim programında yer alan kültürel mirasa duyarlılık değerine ilişkin öğrenci algılarının incelenmesi, Journal of World of Turks, 5(3), 113-137.

Kılcan, B. \& Akbaba, B. (2014). Sosyal bilgiler öğretim programında yer alan estetik değerine ilişkin öğrenci algılarının incelenmesi, Eğitimde Kuram ve Uygulama, 10(4), 1047-1076.

Merriam, S. B. (2013). Araştırmanın desenlenmesi ve örneklem seçimi (Çev. S.Turan ve D.Yılmaz), S. Turan (Çev. Ed.), Nitel araştırma desen ve uygulama için bir rehber, Ankara. Nobel. 55-82.

Miles, M. B. \& Huberman, A. M. (1994). Qualitative data analysis (2nd ed.). Thousand Oaks, CA: SAGE. 
Öztürk, C. \& Otluoğlu, R. (2005). Sosyal bilgiler öğretiminde edebi ürünler ve yazıl materyaller (3. Bask1), Ankara: Pegem.

Patton, M. Q. (2002). Qualitative research and evaluation methods (3rd ed.). London:Sage.

Saban, A. (2008a). İlköğretim I. kademe öğretmen ve öğrencilerinin bilgi kavramına ilişkin sahip oldukları zihinsel imgeler, İlköğretim Online, 7(2), 421-455.

Saban, A. (2008b). Okula ilişkin metaforlar, Kuram ve Uygulamada Eğitim Yönetimi, 55, 459-496.

Saban, A. (2009). Öğretmen adaylarının öğrenci kavramına ilişkin sahip oldukları zihinsel imgeler, Türk Eğitim Bilimleri Dergisi, 7(2), 281-326.

Tosun, C. (2000). Hoca Ahmed Yesevi, hayat1, eserleri ve toplumu eğitme metodu, Dini Araştırmalar 2(6), 119-132.

Yıldırım, A. \& Şimşek, H. (2006). Sosyal bilimlerde nitel araştırma yöntemleri (6. Baskı). Ankara: Seçkin.

Yılmaz, K. (1997). Ahmed Yesevi’nin şöhreti ve tesiri, Türkiyat Araştırmaları Dergisi, Sayı 3, 59-69. 